\title{
Quality Characteristics and Radioactive Contamination of Wood Pellet Imported in
} Italy

\author{
Massimo Calabrese ${ }^{1 *}$, Matteo Quarantotto ${ }^{2}$, Chiara Cantaluppi ${ }^{3}$, Andrea Fasson ${ }^{3}$, \\ Paolo Bogoni ${ }^{1}$ \\ ${ }^{1}$ Department of Economics, Business, Mathematics and Statistics, University of Trieste, Trieste, Italy \\ ${ }^{2}$ University of Trieste, Trieste, Italy \\ ${ }^{3}$ Institute for Energetics and Interphases, National Research Council of Italy, Padova, Italy \\ Email: ${ }^{*}$ massimo.calabrese@deams.units.it
}

Received 8 April 2015; accepted 9 May 2015; published 12 May 2015

Copyright $(2015$ by authors and Scientific Research Publishing Inc.

This work is licensed under the Creative Commons Attribution International License (CC BY).

http://creativecommons.org/licenses/by/4.0/

(c) (i) Open Access

\section{Abstract}

The problem of Caesium-137 (137 Cs) contamination of the imported wood pellet used for burning has been reported in Italy since June 2009. Since then, sampling and analysis were performed at the crossing border points of the provinces of Trieste and Gorizia, on request of the Health and Customs Border Bureau. This paper presents the results of the analysis performed on 65 samples from August 2010 to March 2012, which covered a total of products over 1500 tons of various origins, imported from Eastern Europe and the Balkans. Most of the samples showed very low 137 Cs activity concentrations; only a few hot spots showed 137 Cs activity concentrations higher than $100 \mathrm{~Bq} \cdot \mathrm{kg}^{-1}$. The results of dose evaluations for wood pellet stoves users under the hypotheses assumed in this study were largely below the threshold of radiological relevance.

\section{Keywords}

Radioactivity, Wood Pellet, Biofuels, Caesium-137, Radioprotection

\section{Introduction}

At present, the conglomerate wood pellet represents one of the most used biomass heat sources. It is obtained through simple mechanical processes, during which very fine sawdust is exposed to high pressures and contemporaneously is passed through a spinner with $6-12 \mathrm{~mm}$ holes. The heat produced during these steps activates the lignin, a substance naturally present in the wood, bringing into operation its binding property that determines 
the characteristic compactness and cylindrical shape of the product. The wood pellet represents a valid alternative to traditional heating fuels, because it is easily available, practical to transport, ecological and safe. It is usually packed in $15 \mathrm{~kg}$ bags, not cumbersome and easy to move. The main characteristics of wood pellet (see Table 1) are the high thermal efficiency (over $80 \%)$ and the very low amount of residual ashes $(0.3 \%-0.6 \%)$. The demand of wood pellet constantly rose during the last years, causing an obvious remarkable increase of its price, even if it is still competitive with respect to traditional fossil fuels. The thermal efficiency of this material depends on the quality of wood used for its production. Generally, the best wood pellet is obtained from fir or beech wood; it must have a light or "white" colour, and the label on the package must report its main characteristics (thermal efficiency, place of origin, etc.) and quality references according to international regulations such as DIN 51731 or Ö-NORM M7135 [1]. Also, it must have regular shape and dimensions, corresponding to those reported on packages; it must not have excessive amounts of residual sawdust, and it must be smooth, compact and shiny.

There are many different good quality wood pellets, even if the darkest ones should be evaluated more carefully. About the latter, it must be considered that wood pellet stoves are adjusted to be used with the most widespread wood pellets (light colored, produced from fir or beech wood); the use of other wood pellets may cause malfunctions and lower performances, so an appropriate adjustment of burners should be necessary. Generally, wood pellet is mainly produced in countries with large woody surfaces available (such as Russia, Canada, Sweden, Germany, Austria, Switzerland and the Baltic countries). Italy is a large consumer of wood pellet, but it is not a great producer (there are only some small facilities in north-eastern and in central regions), and then wood pellets for sale are almost exclusively imported. Instead, Italy is a large producer of wood pellet-based heating systems (stoves, boilers, fireplaces) and it is a large market for them [2].

\section{Italian and European Legislation References}

At present in Italy, such as in the other UE countries, there is a lack of legislation protecting consumers about the wood pellet quality. The main European requirements for wood pellet are listed in Table 2; however, a specific limit for Caesium-137 (137 Cs) is not established.

Some Italian national producers, united in the association AIEL ("Associazione Italiana Energie Agroforestali”, Italian Agroforestry Energy Association), voluntarily trusted the quality of their product to the trademark "Pellet Gold", which is based on the standard UNI/TS 11263:2007 [3]. For some aspects, this trademark [4] is more restrictive than the cited UNI/TS rule; for example, an additional parameter, here introduced and not present in any other certification requirement, is the formaldehyde content, which is fundamental to notify the presence of potentially harmful chemicals, such as glues and paints. A limit of $6 \mathrm{~Bq} \cdot \mathrm{kg}^{-1}$ for the overall radioactivity of the product is also established, but no explanation about such a value is given, neither which radionuclides are to be monitored.

\section{The Radioactive Contamination of Wood Pellet}

The problem of radioactive contamination of wood pellet arose in Italy in June 2009 on an imported product, after a series of analysis required by consumers unsatisfied with the quality of the purchased goods.

The "Naturkraft" brand wood pellet, imported from Lithuania, was casually found to be contaminated by 137 Cs; for this reason the local authority "Pretura" (magistrate's court) in Aosta ordered to confiscate it over the

Table 1. Main technical characteristics of a good quality wood pellet [2].

\begin{tabular}{cc}
\hline Characteristic & Typical value \\
\hline Diameter & $6-12 \mathrm{~mm}$ \\
Lenght & $15-50 \mathrm{~mm}$ \\
Density & $1150-1400 \mathrm{~kg} \cdot \mathrm{m}^{-3}$ \\
Humidity & $8 \%-12 \%$ \\
Thermal power & $4.7-5.5 \mathrm{~kW}^{\mathrm{kg}} \mathrm{kg}^{-3}$ \\
Residual ashes & $0.3 \%-0.6 \%$ \\
\hline
\end{tabular}


Table 2. European requirements for wood pellet.

\begin{tabular}{|c|c|c|c|c|c|c|}
\hline Specifications & Units & $\mathrm{CEN} / \mathrm{TS}^{\mathrm{a}}$ & Austria & Germany & Sweden $^{\mathrm{b}}$ & PFI (US) \\
\hline Gross calorific value & $\mathrm{MJ} / \mathrm{kg}$ & $20.00-20.47$ & $>18.00$ & $17.45-19.54$ & $>16.91$ & 18.61 \\
\hline Ash & $\%, d w$ & 0.3 & $<0.5$ & $<1.5$ & $\leq 0.7$ & $<1$ \\
\hline Moisture & $\%$, as received & $<10$ & $<12$ & $<12$ & $\leq 10$ & $<8$ \\
\hline Chlorides & ppm & $<100-300$ & $<200$ & $<300$ & $\leq 300$ & $<300$ \\
\hline Sulphur & $\%$ & $<0.01-0.005$ & $<0.04$ & 0.08 & $\leq 0.08$ & \\
\hline Nitrogen & $\%$ & $<0.1-0.5$ & $<0.30$ & 0.3 & & \\
\hline Arsenic & $\mathrm{mg} / \mathrm{kg}$ & & & 0.8 & & \\
\hline Cadmium & $\mathrm{mg} / \mathrm{kg}$ & 0.1 & & 0.5 & & \\
\hline Chromium & $\mathrm{mg} / \mathrm{kg}$ & 1 & & 8 & & \\
\hline Copper & $\mathrm{mg} / \mathrm{kg}$ & 2 & & 5 & & \\
\hline Mercury & $\mathrm{mg} / \mathrm{kg}$ & & & 0.05 & & \\
\hline Lead & $\mathrm{mg} / \mathrm{kg}$ & & & $<10$ & & \\
\hline Zinc & $\mathrm{mg} / \mathrm{kg}$ & 10 & & $<100$ & & \\
\hline
\end{tabular}

${ }^{a}$ European committee for standardization as given in CEN/TS 14961 "Annex A” examples of specifications for high quality classes of solid biofuels recommended for household usage; ${ }^{b}$ Sweden Group 1 (best) specification [5].

entire national territory, for a total amount of 10,000 tons. After this event, some initiatives were undertaken by many organisations to evaluate the real risk for public health and to propose limits, if necessary. In this case, the Agency for Customs ordered radiometric controls on imported stocks similarly to other goods. It must be observed that wood pellet is not subject by current laws to any radiometric limit in all the EU countries. In fact the activity concentration limit of $1 \mathrm{~Bq} \cdot \mathrm{kg}^{-1}$ provided for by the Italian regulation, legislative decree 230/95 (D. Lgs, 1995) is referred only to practices with radioactive materials; so, in this case, it must be intended only as a reference value, as burning wood pellet cannot be considered a practice with radioactive materials. The problem of the 137 Cs content of wood pellet arises from the fact that this product is imported to be used as a fuel in heating systems. The combustion causes a concentration of mineral salts, 137 Cs among them, roughly of a factor 100 200 and the ashes derived from also slightly contaminated wood pellet could therefore have an high 137 Cs activity concentration and could be potentially an health hazard. Radioprotection problems may arise in the management of wood pellet ashes during the cleaning operations of the domestic stoves, because they are a waste containing $137 \mathrm{Cs}$, even if, as above reported, they cannot be considered a "radioactive waste" as described by the legislative decree 230/95 [6]. From an environmental point of view, the most relevant worry is due to the use of the ashes as fertilizers for orchards and gardens. It must be noted that the health risk for population was initially evaluated as "non-significant” by the ARPA ("Agenzia Regionale per la Protezione Ambientale”, Regional Agency for Environmental Protection) of region Piedmont [7]. In fact, the dose ${ }^{1}$ value for the population was estimated very low, far from the levels of radiological concern $\left(10 \mu \mathrm{Sv} \cdot \mathrm{year}^{-1}\right)$, even if authors themselves reserved to update their evaluation when further data would become available. Shortly afterwards, a study of University of Pavia found a similar conclusion [8].

The Lithuanian "Naturkraft" wood pellet brand was partially released from attachment in September, 2009, except for the batch sequestrated in Region Valle d'Aosta. Since then, the competent Customs Offices continued to require a certificate of radiological conformity for imported batches through gamma-rays spectrometry analysis, to measure the amount of the potential contamination by 137 Cs. These analyses were performed even in absence of a limit for the considered material, as at present there are no limits for this good. This situation seems to be almost partially due to ISPRA ("Istituto Superiore per la Protezione e la Ricerca Ambientale”, National Institute for Environmental Protection and Research) doubts about the effect of accumulation of 137 Cs in ashes,

\footnotetext{
${ }^{1}$ Radiation protection quantity that indicates the amount of energy for unit mass absorbed by an organism exposed to ionizing radiations; it is used also for estimating the risk of long term stochastic health effects following radiation exposure.
} 
which could spread in the environment in an uncontrolled manner, and accumulate in the food chain. In fact, if the amount of wood pellet imported in Italy is considered, a hypothetical contamination of only a few $\mathrm{Bq} \cdot \mathrm{kg}^{-1}$ would imply the introduction in the Italian boundaries of some thousands of $\mathrm{MBq}$ of $137 \mathrm{Cs}$ for year. This amount, even if diluted in a very large bulk, can give a considerable worry about the doses that could be received by particular groups of the population. The topic addressed in this paper results from the need of estimating the amount of $137 \mathrm{Cs}$ in the imported wood pellet used as heating fuel.

\section{Materials and Methods}

From August, 2010 until March, 2012, during the radiological survey carried out in the customs area of Trieste and Gorizia, and co-ordinated with the local Agency for Customs, 65 samples of wood pellet were collected and analysed, each one derived from a single bulk. The determination of the $137 \mathrm{Cs}$ and the Potassium- 40 (40 K) activity concentration was performed through high resolution gamma spectrometry. The instrument used is based on an intrinsic hyper-pure Germanium detector with Be window; the major characteristics of the detector are listed in Table 3. The efficiency and energy calibrations were obtained by means of certified gamma reference standards of mixed radionuclides [9] [10]. Samples were taken, for each charge, from three different bags near the back door of the truck. Afterwards the samples coming from each charge were mixed in order to obtain the average sample for the analysis. The untreated average sample were put each one in $1 \mathrm{~L}$ Marinelli beaker; all the measurements were performed with a low background configuration.

\section{Results and Discussion}

The main data regarding the analysed wood pellet samples and the results of gamma spectrometry analysis are reported in Table 4. The $40 \mathrm{~K}$ activity concentrations found and the data spread are in agreement with $40 \mathrm{~K}$ contents normally found in wood. Also $137 \mathrm{Cs}$ is found in wood as a result of its presence in the environment, in consequence of weapon tests and of Chernobyl accident. 134 Cs (which has the same origin of 137 Cs) in all the analysed samples was always below the detection limits; anyway, it must be noted that its half-life time (2.07 years) is shorter than 137 Cs (30.17 years), so it underwent a larger decay. The total imported wood pellet amount in the considered period was 1550 tons, with an average activity of $13.2 \mathrm{~Bq} \cdot \mathrm{kg}^{-1}$ for $137 \mathrm{Cs}$, and of 43.0 $\mathrm{Bq} \cdot \mathrm{kg}^{-1}$ for $40 \mathrm{~K}$; then, the theoretical total amount of imported $137 \mathrm{Cs}$ should be $20.46 \mathrm{MBq}$. As reported in Table 4, the highest values were found in three samples coming from Ukraine and exceeding $100 \mathrm{~Bq} \cdot \mathrm{kg}^{-1}$; in all the other samples $137 \mathrm{Cs}$ was generally less than $10 \mathrm{~Bq} \cdot \mathrm{kg}^{-1}$. Considering the quality and healthy of wood pellet, especially from a radioprotection aspect, it should be important to avoid the importation of products made with the cortex of trees, which is responsible for the bio-accumulation of mineral salts and metals and then also of most of 137 Cs [11] [12]. This kind of product can be generally distinguished by its dark brown colour; for this reason, clear wood pellet should be preferred.

Table 3. Main characteristics of the germanium detector used.

$\begin{array}{cc}\text { Characteristic } & \text { Typical value } \\ \text { Detector type } & \text { Coaxial, N-type, with Be window } \\ \text { Constructor } & \text { Canberra } \\ \text { Diameter } & 53.5 \mathrm{~mm} \\ \text { Length } & 53.0 \mathrm{~mm} \\ \text { Distance between Ge detector and Be window } & 5 \mathrm{~mm} \\ \text { FWHM (Full Width at Half Maximum) (at } 122 \mathrm{keV}) & 0.81 \mathrm{keV} \\ \text { FWHM (at } 1332 \mathrm{keV}) & 1.73 \mathrm{keV} \\ \text { Peak/Compton } & 55.9 / 1 \text { (at } 1332 \mathrm{keV}) \\ \text { Relative efficiency } & 25.3 \% \text { (at } 1332 \mathrm{keV}) \\ \text { Depletion voltage } & -2500 \mathrm{~V} \\ \text { Recommended voltage } & -4000 \mathrm{~V}\end{array}$


Table 4. Collected samples.

\begin{tabular}{|c|c|c|c|c|c|c|}
\hline No. & Date & Origin & Amount (tons) & Customs & ${ }^{137} \mathrm{Cs}\left(\mathrm{Bq} \cdot \mathrm{kg}^{-1}\right)$ & ${ }^{40} \mathrm{~K}\left(\mathrm{~Bq} \cdot \mathrm{kg}^{-1}\right)$ \\
\hline 1 & 17.08.2010 & Croatia & 24.150 & GO & 5.4 & 58.1 \\
\hline 2 & 17.08.2010 & Croatia & 24.882 & GO & 0.6 & 38.0 \\
\hline 3 & 23.08 .2010 & Croatia & 24.625 & GO & 6.5 & 29.0 \\
\hline 4 & 03.09.2010 & Croatia & 24.150 & GO & 2.5 & 50.3 \\
\hline 5 & 28.09.2010 & Croatia & 25.200 & TS & 3.7 & 47.8 \\
\hline 6 & 29.09 .2010 & Croatia & 25.200 & TS & $<0.5$ & 73.3 \\
\hline 7 & 06.10 .2010 & Croatia & 24.400 & TS & $<0.5$ & 46.9 \\
\hline 8 & 08.10 .2010 & Croatia & 24.495 & Mn & 3.5 & 53.0 \\
\hline 9 & 12.10 .2010 & Serbia & 24.500 & GO & 4.3 & 52.0 \\
\hline 10 & 12.10 .2010 & Croatia & 25.200 & TS & 2.4 & 32.8 \\
\hline 11 & 14.10 .2010 & Croatia & 25.200 & TS & 2.5 & 35.8 \\
\hline 12 & 28.10 .2010 & Croatia & 25.200 & TS & $<0.5$ & 28.0 \\
\hline 13 & 29.10 .2010 & Bosnia & 24.360 & TS & 0.7 & 42.4 \\
\hline 14 & 04.11 .2010 & Bosnia & 24.600 & TS & 3.9 & 67.1 \\
\hline 15 & 04.11 .2010 & Russia & 22.000 & GO & 39.5 & 51.0 \\
\hline 16 & 05.11 .2010 & Croatia & 25.200 & GO & 2.5 & 23.7 \\
\hline 17 & 11.11 .2010 & Croatia & 16.600 & GO & 2.8 & 52.0 \\
\hline 18 & 15.11.2010 & Bosnia & 24.600 & TS & 5.5 & 41.8 \\
\hline 19 & 15.11.2010 & Serbia & 24.500 & GO & 9.9 & 59.0 \\
\hline 20 & 25.11.2010 & Bosnia & 24.600 & TS & 5.5 & 31.0 \\
\hline 21 & 30.11 .2010 & Croatia & 25.880 & GO & 7.9 & 44.0 \\
\hline 22 & 09.12.2010 & Croatia & 25.200 & GO & 4.2 & 29.0 \\
\hline 23 & 13.12.2010 & Croatia & 24.720 & GO & 3.6 & 36.8 \\
\hline 24 & 14.12 .2010 & Croatia & 25.200 & TS & 6.7 & 48.5 \\
\hline 25 & 16.12 .2010 & Serbia & 24.500 & GO & 0.7 & 23.0 \\
\hline 26 & 17.12 .2010 & Croatia & 22.950 & GO & 2.5 & 36.6 \\
\hline 27 & 22.12.2010 & Bosnia & 24.360 & TS & 3.4 & 34.7 \\
\hline 28 & 23.12.2010 & Croatia & 22.400 & GO & 5.5 & 62.0 \\
\hline 29 & 10.01.2011 & Croatia & 25.200 & TS & 4.3 & 29.6 \\
\hline 30 & 13.01 .2011 & Croatia & 23.058 & $\mathrm{Mn}$ & 5.0 & 47.2 \\
\hline 31 & 13.01 .2011 & Croatia & 23.600 & TS & 7.0 & 38.9 \\
\hline 32 & 19.01.2011 & Ukraine & 22.000 & GO & 110.0 & 35.5 \\
\hline 33 & 27.01.2011 & Croatia & 25.200 & Mn & 2.5 & 21.8 \\
\hline 34 & 27.01 .2011 & Croatia & 23.600 & TS & 4.4 & 26.0 \\
\hline
\end{tabular}




\section{Continued}

\begin{tabular}{|c|c|c|c|c|c|c|}
\hline 35 & 27.01.2011 & Croatia & 23.600 & TS & 3.7 & 50.2 \\
\hline 36 & 28.01.2011 & Bosnia & 24.480 & TS & 5.8 & 28.4 \\
\hline 37 & 04.02.2011 & Bosnia & 24.480 & TS & 9.0 & 43.5 \\
\hline 38 & 07.02.2011 & Ukraine & 20.650 & TS & $<0.5$ & 71.6 \\
\hline 39 & 10.02 .2011 & Croatia & 24.495 & $\mathrm{Mn}$ & 4.5 & 42.1 \\
\hline 40 & 12.02.2011 & Ukraine & 19.800 & TS & 0.6 & 49.3 \\
\hline 41 & 15.02 .2011 & Croatia & 25.200 & Mn & 0.6 & 66.0 \\
\hline 42 & 17.02.2011 & Croatia & 23.058 & $\mathrm{Mn}$ & 4.2 & 47.3 \\
\hline 43 & 24.02.2011 & Bosnia & 24.360 & TS & 8.7 & 39.0 \\
\hline 44 & 14.03 .2011 & Croatia & 24.030 & Mn & 1.7 & 29.6 \\
\hline 45 & 25.03.2011 & Croatia & 23.935 & $\mathrm{Mn}$ & 3.2 & 25.5 \\
\hline 46 & 28.03.2011 & Bosnia & 24.000 & Mn & 2.5 & 24.0 \\
\hline 47 & 26.04.2011 & Bosnia & 24.000 & $\mathrm{Mn}$ & 8.3 & 45.7 \\
\hline 48 & 06.05.2011 & Croatia & 25.200 & Mn & 3.7 & 39.0 \\
\hline 49 & 11.05 .2011 & Bosnia & 24.360 & TS & 6.5 & 44.4 \\
\hline 50 & 23.05.2011 & Croatia & 24.350 & $\mathrm{Mn}$ & 5.5 & 43.2 \\
\hline 51 & 21.10 .2011 & Croatia & 25.000 & TS & 6.6 & 39.0 \\
\hline 52 & 24.10 .2011 & Bosnia & 24.480 & TS & 6.7 & 58.3 \\
\hline 53 & 14.11 .2011 & Ukraine & 21.600 & TS & 0.9 & 27.0 \\
\hline 54 & 18.11.2011 & Ukraine & 21.600 & TS & 1.5 & 36.9 \\
\hline 55 & 29.11.2011 & Ukraine & 22.044 & TS & 85.3 & 72.0 \\
\hline 56 & 11.01 .2012 & Bosnia & 24.480 & TS & 5.1 & 67.7 \\
\hline 57 & 13.01.2012 & Croatia & 25.000 & TS & 6.6 & 25.4 \\
\hline 58 & 16.01.2012 & Ukraine & 21.966 & TS & 10.0 & 47.7 \\
\hline 59 & 16.01 .2012 & Ukraine & 21.044 & TS & 107.1 & 54.0 \\
\hline 60 & 19.01.2012 & Bosnia & 24.480 & TS & 5.6 & 38.6 \\
\hline 61 & 31.01 .2012 & Ukraine & 22.250 & TS & 0.9 & 58.0 \\
\hline 62 & 3.02.2012 & Croatia & 25.000 & TS & 6.2 & 50.5 \\
\hline 63 & 13.02.2012 & Ukraine & 22.044 & TS & 89.4 & 41.0 \\
\hline 64 & 17.02.2012 & Croatia & 25.000 & TS & 5.1 & 27.8 \\
\hline \multirow[t]{5}{*}{65} & 15.03 .2012 & Ukraine & 22.044 & TS & 129.3 & 34.6 \\
\hline & & MEAN & & & 13.2 & 43.0 \\
\hline & \multicolumn{3}{|c|}{ Standard deviation } & & 28.26 & 13.3 \\
\hline & \multicolumn{3}{|c|}{ Minimum value } & & 0.6 & 21.8 \\
\hline & \multicolumn{3}{|c|}{ Maximum value } & & 129.3 & 73.3 \\
\hline
\end{tabular}

TS = Trieste trucks terminal-industrial harbour, Monrupino; GO = S. Andrea trucks terminal, Gorizia; $\mathrm{Mn}$ = Monfalcone harbour. 
As far as radioprotection is concerned, the main worry regards $137 \mathrm{Cs}$ concentration in ashes, as concentration factors ashes/pellets of 100 - 200 are reported. If ashes have a high 137 Cs activity, the periodic cleaning of stoves from ashes may cause external irradiation dose and potentially also inhalation dose due to resuspended ashes. It is possible to estimate the dose from irradiation and inhalation considering different hypothetical scenarios:

a) a flat (about $70-80 \mathrm{~m}^{2}$ ) in Central Italy using a wood pellet stove only for heating, consuming about 1620 $\mathrm{kg}$ of wood pellets for year (small consumer);

b) a single house (more than $150 \mathrm{~m}^{2}$ ) in Northern Italy using the pellet stove also for hot water production, consuming about $6376 \mathrm{~kg}$ of wood pellets for year (large consumer);

c) a central heating system for a condominium of 10 flats, consuming about 15,000 kg of wood pellets per year.

The external irradiation absorbed dose received over the course of one year was estimated for the three scenarios above (Table 5), on the basis of the maximum 137 Cs activity concentration in wood pellets found in this paper (110 Bq.kg $\left.{ }^{-1}\right)$. Cases b) and c) consider critical groups of the population from radioprotection point of view, since the calculations regard the most exposed people (i.e. those which periodically clean the stove) in cases of high 137 Cs activity concentration and a strong use of wood pellet stoves. The inhalation absorbed dose for the three scenarios was calculated in Table 6. From the results of Table 5 and Table 6 the prevailing dose contribution is due to inhalation. The contribution, in any case very low, can be also lower if the periodic cleaning of the stove is done with vacuum cleaners instead of by hand. The choice of a reference level for the $137 \mathrm{Cs}$

Table 5. Irradiation dose estimation for three scenarios.

\begin{tabular}{|c|c|c|c|}
\hline & Flat in Central Italy & $\begin{array}{l}\text { Single House } \\
\text { in Northern Italy }\end{array}$ & Condominium Stove \\
\hline Mass of wood pellets burned in one year $\left(\mathrm{kg} \cdot \mathrm{year}^{-1}\right)$ & 1620 & 6376 & 15,000 \\
\hline Concentration factor pellets/ashes & 150 & 150 & 150 \\
\hline Mass of ashes produced in one year $\left(\mathrm{kg} \cdot \mathrm{year}^{-1}\right)$ & 10.8 & 42.5 & 100 \\
\hline${ }^{137} \mathrm{Cs}$ activity concentration in pellets $\left(\mathrm{Bq} \cdot \mathrm{kg}^{-1}\right)$ & 110 & 110 & 110 \\
\hline${ }^{137}$ Cs activity concentration in ashes $\left(\mathrm{Bq} \cdot \mathrm{kg}^{-1}\right)$ & 16,500 & 16,500 & 16,500 \\
\hline Mass of ashes removed for each cleaning operation (kg) & 1 & 1.42 & 4 \\
\hline Maintenance operation duration (minutes) & 10 & 10 & 60 \\
\hline Number of maintenance operations repetitions & 11 & 30 & 25 \\
\hline Mean distance from ashes (m) & 0.4 & 0.4 & 0.6 \\
\hline Dose rate at $1 \mathrm{~m}$ distance for $1 \mathrm{MBq}$ of ${ }^{137} \mathrm{Cs}\left(\mathrm{nSv} \cdot \mathrm{h}^{-1}\right)$ & 75 & 75 & 75 \\
\hline Dose rate at operation distance for $1 \mathrm{MBq}$ of ${ }^{137} \mathrm{Cs}\left(\mathrm{nSv} \cdot \mathrm{h}^{-1}\right)$ & 468.8 & 468.8 & 208.3 \\
\hline Irradiation dose for one year (nSv) & 14.2 & 54.9 & 343.8 \\
\hline
\end{tabular}

Table 6. Inhalation dose estimation for three scenarios.

\begin{tabular}{|c|c|c|c|}
\hline & $\begin{array}{c}\text { Flat } \\
\text { in Central Italy }\end{array}$ & $\begin{array}{c}\text { Single House } \\
\text { in Northern Italy }\end{array}$ & Condominium Stove \\
\hline Concentration of the dust resuspended in air $\left(\mu \mathrm{g} \cdot \mathrm{m}^{-3}\right)$ & 50 & 50 & 50 \\
\hline Breathing rate $\left(\mathrm{m}^{3} \cdot\right.$ hour $\left.^{-1}\right)$ & 1.2 & 1.2 & 1.2 \\
\hline Maintenance operation duration (minutes) & 10 & 10 & 60 \\
\hline${ }^{137} \mathrm{Cs}$ activity concentration in ashes $\left(\mathrm{Bq} \cdot \mathrm{kg}^{-1}\right)$ & 16,500 & 16,500 & 16,500 \\
\hline Inhalation dose coefficient for ${ }^{137} \mathrm{Cs}\left(\mathrm{Sv} \cdot \mathrm{Bq}^{-1}\right)$ & $3.9 \mathrm{E}-05$ & $3.9 \mathrm{E}-05$ & $3.9 \mathrm{E}-05$ \\
\hline Number of maintenance operation repetitions & 11 & 30 & 25 \\
\hline Inhalation dose for one year (nSv) & 70.8 & 193.1 & 965.3 \\
\hline
\end{tabular}


content in wood pellets should result from the calculated absorbed dose by critical groups of the population as far as wood pellets use is concerned. However, the reaching of an inhalation dose of $10 \mu \mathrm{Sv} \cdot \mathrm{year}^{-1}$ (under this threshold, the dose is considered as "not relevant" from a radioprotection point of view) would require a 137 Cs activity concentration in wood pellet of about $1200 \mathrm{~Bq} \cdot \mathrm{kg}^{-1}$, never found in Italy so far.

\section{Conclusions}

Most of the imported wood pellet samples showed very low 137 Cs activity concentrations; only a few hot spots showed $137 \mathrm{Cs}$ activity concentrations higher than $100 \mathrm{~Bq} \cdot \mathrm{kg}^{-1}$. This fact and the possibility that radionuclides accumulation in ashes could interest directly critical groups of the population, the food chain and also the environment, can justify the continuation of the current control procedures. However, the dose evaluations for wood pellet stoves users under the hypotheses assumed in this paper were largely below the threshold of radiological relevance.

In addition, the unavoidable presence in wood of natural radionuclides should be taken in account in order to establish reasonable limits for radionuclides content in wood pellet. In fact, the assigned limit of $6 \mathrm{~Bq} \cdot \mathrm{kg}^{-1} \mathrm{for}$ the overall radioactivity of the product [4] seems to be illogical: for example, in this study a mean value for $40 \mathrm{~K}$ (a natural radionuclide) activity concentration was found to be $43.0 \mathrm{~Bq} \cdot \mathrm{kg}^{-1}$.

\section{References}

[1] European Pellet Centre. Pellets for Europe. http://www.pelletcentre.info

[2] Pellet Italia. http://www.pelletitalia.org

[3] Ente Nazionale Italiano di Unificazione-Biocombustibili Solidi (2007-2011) Caratterizzazione dei Pellet ai Fini Energetici Specifiche e Classificazione del Combustibile. UNI/TS 11263—UNI EN 14961—Parte 2.

[4] Associazione Italiana per le Energie Agroforestali (AIEL) (2009) Allegato 3 al "Regolamento Generale Relativo alle Regole Particolari per l'Attestazione di Qualità-Pellet Gold. AIEL, 5-6.

[5] Chandrasekaran, S.R., Hopke, P.K., Rector, L., Allen, G. and Lin, L. (2012) Chemical Composition of Wood Chips and Wood Pellets. Energy \& Fuels, 26, 4932-4937. http://dx.doi.org/10.1021/ef300884k

[6] D. Lgs. no. 230, D. Lgs. 187 and D. Lgs. 241 (1995-2000) Attuazione delle direttive 89/618/Euratom, 90/641/Euratom, 92/3/Euratom e 96/29/Euratom in materia di radiazioni ionizzanti. Gazzetta Ufficiale n.136 del 13-6-1995-Suppl. Ordinario n. 74; Gazzetta Ufficiale n. 203 del 31 agosto 2000-Supplemento Ordinario n. 140; Gazzetta Ufficiale n. 157 del 7 luglio 2000-Supplemento Ordinario n. 105.

[7] Chiaberto, E., Tripodi, R., Bertino, M. and Magnoni, M. (2009) Stima di Dose alla Popolazione Dovuta all’Impiego nelle Stufe di Pellets Radioattivi—Prime Valutazioni. ARPA Piemonte-Relazione tecnica no. 406/IR.

[8] Manera, S. and Dilani, D. (2009) Pellet Radioattivo. Indagine Radiometrica e Considerazioni di Radioprotezione. In: Revisione 2, 15 Luglio 2009, University of Pavia, Pavia.

[9] Ente Nazionale Italiano di Unificazione, Energia Nucleare (1991) Determinazione del 137 Cs per Spettrometria Gamma Diretta. UNI 9890.

[10] Cantaluppi, C. and Degetto, S. (2003) Fast Self-Absorption Correction Procedure for Low Energy $210 \mathrm{~Pb}$ Gamma Emission in Environmental Samples. Annali di Chimica, 93, 649-657.

[11] Brambilla, M., Fortunati, P. and Carini, F. (2003) Modello Concettuale Dinamico per lo Studio del Trasferimento di Radiocesio dal Terreno alle Piante d’Interesse Agrario. Bollettino della Società Italiana della Scienza del Suolo, 52, 343-352.

[12] Donati, S. (2002) Distribuzione del Contenuto di Elementi Chimici Radioattivi e Stabili in Pinus Pinaster e Prospettive di Utilizzo in Dendroanalisi. Environmental Sciences Degree Thesis, University of Bologna, Bologna. 